IOSR Journal of Engineering

May. 2012, Vol. 2(5) pp: 1217-1223

\title{
In- vitro bio-efficacy of some selected fungal antagonists against guava wilt pathogen
}

\author{
S. K Dwivedi ${ }^{1}$, Neetu Dwivedi ${ }^{2}$ \\ Department of Environmental Science, B. B. Ambedkar University (A Central University), Lucknow -226025, U.P., INDIA
}

\begin{abstract}
Five fungal antagonists viz., Aspergillus flavus, Aspergillus luchuensis, Penicilliun citrinum P. chrysogenum and Trichoderma viride were isolated from soil of guava orchards near the bank of river Ganga, Kanpur, following serial dilution plate technique; evaluated against guava wilt pathogen i.e. Fusarium solani at 10\%, 25\%, 50\%, $75 \%$ and 100\% concentration following 'Poisoned food technique'. The antagonists were effective in controlling the growth of test pathogen at different levels. Among the antagonists tested, Aspergillus luchuensis was effective by $89.68 \%\left(3^{\text {rd }}\right.$ day), $92.32 \%\left(5^{\text {th }}\right.$ day) and $93.85 \%$ on $\left(7^{\text {th }}\right.$ day) after inoculation at $100 \%$ concentration followed by Aspergillus flavus and Penicillium citrinum by $78.52 \%$ and $77.96 \%$ ( $3^{\text {rd }}$ day), $84.10 \%$ and $81.86 \%\left(5^{\text {th }}\right.$ day), $87.29 \%$ and $82.59 \%$ on $\left(7^{\text {th }}\right.$ day) respectively. However, P. chrysogenum and Trichoderma viride gave almost similar results and inhibited the mycelial growth of pathogen by $79.50 \%$ and $79.95 \%$ on $7^{\text {th }}$ day after inoculation at $100 \%$ concentration respectively.
\end{abstract}

Keywords: Antagonist, bio-efficacy, guava, wilt disease.

\section{INTRODUCTION}

Guava (Psidium guajava L.) of Myrtaceae family is the sixth most cultivated fruit in India. Tropical and sub-tropical climates support its growth, hence named as "Apple of tropics". Guava is a good source of vitamin 'C', Fats, carbohydrates; and its fruits, leaves, roots, barks are used in local medicines to treat gastroenteritis, diarrhea and dysentery [1,2]. Guava leaf extracts showed an antiviral action against transmission of filamentous plant viruses [3].

Kanpur is a city situated near the bank of river Ganga ( $2630^{\prime}$ on latitude, $8019^{\prime} 60$ longitudes, 115 meters altitude). The city is actively engaged in the production of guava which is contributing major share in the total U.Ps production i.e. (318.9 ha area/ production $4045.1 \mathrm{mt}$ ).Being very hardy, it gives an assured crop even with very little care. But its successful cultivation is hindered by a number of pathogens and causes a serious disease called "wilt of guava", first reported and described from Allahabad.The major agronomic and horticultural problems facing the guava industry are severity of wilt disease and susceptibility to many pathogens and stresses, low yield and short fruit shelf life, high seed content etc [4]. The disease is caused by different pathogens viz., Fusarium sp. [5, 6, 7, 8],Gloesporium psidii [9], Fusarium oxysporum f.sp. psidii, F. solani, F. coeruleum, F. moniliforme, Rhizoctonia solani [10,11] and Macrophomina phaseolina [12]. It is the most destructive disease of guava and causes 5-60\% loss in guava production in India [13]. Symptoms of the disease are the yellow colouration with slight leaf curling at the terminal branches, becoming reddish, premature shedding of leaves so Fusarium oxysporum and $F$. sonali were found most dominant fungi $[14,15]$. The disease is soil-borne and poses a greater problem in management by using fungicides and other chemical based treatments. These are uneconomical and moreover, their fast and indiscriminate use often leads to environmental problems and development of resistance in the pathogens. Therefore, the present study was undertaken to evaluate the efficiency of biological agents such as Aspergillus flavus, Aspergillus luchensis, Penicilliun citrinum, Penicillium chrysogenum and Trichoderma viride against Fusarium solani causing wilt of guava.

\section{Materials and Methods}

\subsection{Isolation of fungal population}

The soil samples (rhizospheric and non-rhizospheric regions) and affected plant parts of wilted trees were taken from guava orchards in polythene bags separately near bank of Ganga, Kanpur in all three seasons i.e. summer, rainy and winter during 2009-2010. The Fungal isolation from soil was done by dilution plate method, while infected plant parts were examined under microscope after cutting down the samples into small pieces manually. Then the samples were sterilized with $0.1 \%$ mercuric chloride for 30 seconds. After sterilization the samples were washed thrice with distilled water and soaked with sterilized blotting paper and transferred aseptically on C-zapex Dox agar medium plates and incubated at $28 \pm 2^{\circ} \mathrm{C}$ for 7 days. After the appearance of colonies on plate, separate slides were prepared for microscopic study and identified each slides with the help of literature available. 
IOSR Journal of Engineering

May. 2012, Vol. 2(5) pp: 1217-1223

\subsection{Broth preparation for antagonists}

Pure culture of all antagonists viz., Aspergillus flavus, Aspergillus luchensis, Penicilliun citrinum Penicillium chrysogenum and Trichoderma viride were separately inoculated (Agar blocks- $5 \mathrm{~mm}$ diam) into $250 \mathrm{ml}$ of Czapek- Dox broth in $500 \mathrm{ml}$ conical flask and incubated at $28 \pm 1{ }^{\circ} \mathrm{C}$ for 15 days. After formation of complete mycelial growth the cultures were filtered firstly through normal filter paper and then Whatman filter paper no. 42. Broth of antagonist and amended agar medium were added separately to maintain desired concentrations i.e. 10\%, 25\%, 50\%, 75\% and 100\%. Poured the fix amount of medium in Petriplates and allowed to solidify. These Petriplates were inoculated with $2 \mathrm{~mm}$ disc, taken from the periphery of 7-day old culture of target pathogen and incubated at $28 \pm 1^{\circ} \mathrm{C}$ for a week. All the treatments were set in triplicate with control (without antagonist). Radial growth of test fungi was recorded on $3^{\text {rd }}, 4^{\text {th and }} 7^{\text {th }}$ day after inoculation. Percent inhibition was calculated by following formula given by Sundar et al. (1995) [16].

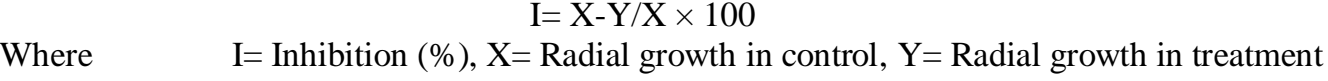

2.3 Statistical Analysis

The data were calculated as Mean $\pm \mathrm{SE}$ and analyzed using analysis of variance technique (ANOVA). Probability of 0.05 or less was considered significant according to Duncan's Multiple Range test.

\section{RESULTS AND DISCUSSION}

\subsection{Isolation of fungal population}

A total 21 fungal species were isolated from rhizospheric and non-rhizospheric regions of soil and plant parts (root and stem) of guava orchards in all three seasons of sampling (Table 1). Among 21species isolated Fusarium solani and Fusarium oxysporum was found most dominant one in all three seasons followed by Aspergillus flavus, A. luchuensis, Trichoderma viride, Fusarium oxysporum $f$. sp. psidii Alternaria alternate, Curvularia lunata, Penicillium citrinum and white sterile mycelia similar to the findings of Zhang et al (1995), isolated Fusarium solani and Fusarium oxysporum from healthy looking roots of cotton seedlings grown in cotton field soil. [17] .The least dominant species was A. sulfureous followed by F.moniliformae, Macrophomina phaseolina, T.lignorum and Aspergillus candidus supports the study of Kumar and Dubey (2001) [18]. It was found that the summer and rainy season supports the survivorship of the fungal species in soil. The stem of the guava plant found to be affected with Fusarium solani. This result coincides with the findings of earlier work in west Bengal (Chattopadhyay and Bhattacharjya, 1968) [19]. Mishra and Pandey, 1999; Gupta and Mishra, 2011) have reported Fusarium solani and Fusarium oxysporum f. $s p$. psidii as a serious pathogens of guava orchards [20,21].

Dolly et al., (2006); Gupta et al, (2009) and Gupta et al, (2011) also isolated Fusarium oxysporumf. sp. psidii from wilted guava roots and reported that Aug- Oct was the most favorable period for the development of the pathogen whereas May- July was found least favorable period. [22, 23, 24] Dominance of population of Fusarium oxysporum f. sp. psidii in rainy season as in present study agreed with the findings of Dwivedi, (1991) [25]. Siva et al., 2008 for Brinjal; Obongoya et al., 2010, (for common bean) and Gangadara et al., 2010 (for Vanilla) isolated Fusarium oxysporum from affected parts of root and stem [26, 27, 28].

\subsection{Efficacy of Antagonists}

All the fungal antagonists under the study had shown virulent activity against Fusarium solani causing wilt in guava. It was found from the experiment (Fig 1) on $3^{\text {rd }}$ day after inoculation Aspergillus luchuensis was significantly diminished the mean radial growth of the test pathogen by $81.8 \%$ and $89.68 \%$ at $75 \%$ and $100 \%$ concentration followed by Aspergillus flavus (75.59 and 78.52) and Trichoderma viride (78\% and 78.32\%) significant at level ( $\mathrm{p}<0.05$ ) (Table 2). Penicillium citrinum and $P$. chrysogenum were found least effective and reduced the mean radial growth by $77.96 \%$ and $74.89 \%$ at $100 \%$ concentration respectively.Data presented in (Fig 2) revealed that on $5^{\text {th }}$ day again Aspergillus luchuensis was significantly diminished the mean radial growth of the test pathogen by $87.95 \%$ and $92.32 \%$ at $75 \%$ and $100 \%$ concentration followed by Aspergillus flavus (82.31\% and $84.10 \%)$ and Penicillium citrinum $(81.86 \%)$ at $100 \%$ concentration significant at level $(\mathrm{p}<0.05)($ Table 2$)$. Whereas $P$. chrysogenum was found effective than Trichoderma viride and inhibited the mycelial growth of Fusarium solani by $79.45 \%$ and $78.99 \%$ at $100 \%$ concentration respectively. 
IOSR Journal of Engineering

May. 2012, Vol. 2(5) pp: 1217-1223

Table 1: Fungal population isolated from guava orchards during different seasons

\begin{tabular}{|l|l|l|l|l|l|l|l|l|l|l|}
\hline Fungal population & \multicolumn{3}{|c|}{ SUMMER } & \multicolumn{3}{c|}{ RAINY } & \multicolumn{3}{c|}{ WINTER } \\
\hline Regions & RS & NRS & PP & RS & NRS & PP & RS & NRS & PP \\
\hline Aspergillus flavus & + & + & + & - & + & - & + & + & + \\
\hline A. luchuensis & + & - & + & + & - & - & - & + & + \\
\hline A. niger & - & + & + & + & + & - & + & - & - \\
\hline Aspergillus candidus & + & - & - & - & - & - & + & - & + \\
\hline Aspergillus sydowi & + & + & - & + & + & - & + & - & - \\
\hline A. sulfureous & + & - & - & - & - & - & + & - & - \\
\hline Alternaria alternata & + & + & - & + & - & + & - & + & + \\
\hline Curvularia lunata & + & + & + & + & + & + & - & + & - \\
\hline Fusarium oxysporum & + & + & + & + & - & + & - & + & + \\
\hline F. solani & + & + & + & + & + & + & - & + & - \\
\hline Fusarium f. sp. psidii & - & + & + & - & + & - & + & + & - \\
\hline F.moniliformae & + & - & - & + & - & + & + & - & - \\
\hline Macrophomina phaseolina & - & + & - & + & + & - & - & - & + \\
\hline Penicillium citrinum & + & + & + & - & + & - & - & + & - \\
\hline P. italicum & + & + & + & - & - & - & - & + & - \\
\hline P. chrysogenum & + & + & - & - & - & - & - & + & + \\
\hline Rhizoctonia solani & + & + & - & + & & + & - & - & + & - \\
\hline Trichoderma viride & - & - & + & + & + & - & - & + & + & - \\
\hline T.lignorum & + & + & + & - & + & - & + & - & - & - \\
\hline T. hamatum & - & + & + & + & - & - & - & + & - & + \\
\hline Rhizoctonia solani, & + & + & + & - & + & + & - & - & - \\
\hline White sterile mycelia & + & + & - & - & + & - & + & + & + \\
\hline
\end{tabular}

\section{RS - Rhizospheric region of soil, NRS- Non rhizospheric region of soil, PP- Plant part, Presence (+), Absence (-)}

Aspergillus luchuensis was significantly diminished the mean radial growth of the test pathogen by $93.85 \%$ followed by Aspergillus flavus $(87.29 \%)$ and and Penicillium citrinum (82.59\%) at $100 \%$ concentration on $7^{\text {th }}$ day significant at level $(\mathrm{p}<$ 0.05) (Table 3, Fig 3). Whereas Trichoderma viride was found superior than P. chrysogenum and inhibited the mycelial growth by $79.95 \%$ and $79.50 \%$ at $100 \%$ concentration respectively.

Dwivedi (1992) reported that Aspergillus flavus was found least effective in case of Fusarium oxysporum f. sp. psidii reducing the growth only by $16.6 \%$ whereas $T$. viride inhibited the growth of Fusarium oxysporum f. sp. psidii by $71.4 \%$, while $T$. harzianum reduced the growth of test pathogens i.e., Fusarium oxysporum f. sp. psidii and F.moniliformae by 60 and $60.4 \%$ respectively [29]. Singh et al., (2003), Mishra and Prasad (2003), Gupta and Mishra, (2009) reported that the isolates of Aspergillus spp, Trichoderma spp and Penicillium citrinum were found superior in inhibiting the growth of Fusariun solani in vitro $[30,31,32]$.

Shovan et al., (2008) isolated 20 strains of T. harzianum from rhizosphere and rhizoplane of different crops and were screened against Colletotrichum dematium causing Antroscnose of soybean. Among the promising antagonist they found that the isolate of $\mathrm{T}_{3}$ of $T$. harzianum showed the highest $89.44 \%$ inhibition of radial growth of Colletotrichum dematium [33].

In a study $T$. viride was found to be most effective to control the Fusarium wilt of pigeonpea [34]. Alwathnani and perveen, (2012) reported that among the antagonists tested maximum inhibition was recorded with A. niger (70\%). However, $P$. citrinum, T. harzianum and Penicillium sp. showed considerable inhibition of 58, 54 and 58\% respectively against Fusarium oxysporum $f$. sp.lycopersici causing wilt in tomato [35]. 
IOSR Journal of Engineering

May. 2012, Vol. 2(5) pp: 1217-1223

Rani et al., (2009) reported T. viridii as effective antagonist to check the growth of Macrophomina phaseolina causing root rot of groundnut [36].Sultana and Ghaffar (2010) reported that microbial antagonists have potential to inhibit the seed infection in cucumber. T. viride was found effective against wilt pathogen of Bittergaurd i.e., Fusarium solani [37]. Segarra et al., (2010) reported that $\mathrm{T}_{34 \text { strain }}$ of $T$. asperellum protected tomato plants from biotic (Fusarium wilt) and abiotic stress (Fe-III) toxic effects caused by Fusarium oxysporum f. sp. lycopersici (fol) [38].

Table 2: Efficacy of antagonists against Fusarium solani on $3^{\text {rd }}$ day after inoculation

\begin{tabular}{|l|l|l|l|l|l|}
\hline Treatments & A. flavus & A. luchuensis & P. citrinum & P.chryosogenum & T. viride \\
\hline $\mathrm{T}_{0}($ Control $)$ & $35.0 \pm 1.73^{\mathrm{a}}$ & $35.0 \pm 1.73^{\mathrm{a}}$ & $35.0 \pm 1.73^{\mathrm{a}}$ & $35.0 \pm 1.73^{\mathrm{a}}$ & $35.0 \pm 1.73^{\mathrm{a}}$ \\
\hline $\mathrm{T}_{1}(10 \%)$ & $13.1 \pm 0.26^{\mathrm{b}}$ & $12.2 \pm 0.26^{\mathrm{b}}$ & $12.3 \pm 0.03^{\mathrm{b}}$ & $14.2 \pm 0.15^{\mathrm{b}}$ & $14.6 \pm 0.18^{\mathrm{b}}$ \\
\hline $\mathrm{T}_{2}(25 \%)$ & $15.4 \pm 2.27^{\mathrm{b}}$ & $10.6 \pm 0.33^{\mathrm{b}}$ & $12.2 \pm 0.05^{\mathrm{b}}$ & $13.7 \pm 0.08^{\mathrm{b}}$ & $13.7 \pm 0.97^{\mathrm{b}}$ \\
\hline $\mathrm{T}_{3}(50 \%)$ & $12.4 \pm 0.14^{\mathrm{b}}$ & $7.70 \pm 0.35^{\mathrm{c}}$ & $12.0 \pm 0.03^{\mathrm{b}}$ & $13.4 \pm 0.08^{\mathrm{b}}$ & $13.3 \pm 0.70^{\mathrm{b}}$ \\
\hline $\mathrm{T}_{4}(75 \%)$ & $8.50 \pm 0.02^{\mathrm{c}}$ & $6.33 \pm 0.08^{\mathrm{c}}$ & $8.80 \pm 0.05^{\mathrm{c}}$ & $11.5 \pm 0.10^{\mathrm{b}}$ & $7.66 \pm 0.04^{\mathrm{c}}$ \\
\hline $\mathrm{T}_{5}(100 \%)$ & $7.48 \pm 0.02^{\mathrm{c}}$ & $3.59 \pm 0.09^{\mathrm{d}}$ & $7.67 \pm 0.04^{\mathrm{c}}$ & $8.75 \pm 0.07^{\mathrm{c}}$ & $7.55 \pm 0.01^{\mathrm{c}}$ \\
\hline CD at $p<0.05$ & 3.65 & 2.31 & 2.20 & 2.22 & 2.69 \\
\hline SEM & 1.17 & 0.74 & 0.70 & 0.71 & 0.86 \\
\hline
\end{tabular}

Table 3: Efficacy of antagonists against Fusarium solani on $5^{\text {th }}$ day after inoculation

\begin{tabular}{|l|l|l|l|l|l|}
\hline Treatments & A. flavus & A. luchuensis & P. citrinum & P.chryosogenum & T. viride \\
\hline $\mathrm{T}_{0}($ Control $)$ & $48.3 \pm 1.85^{\mathrm{a}}$ & $48.3 \pm 1.85^{\mathrm{a}}$ & $48.3 \pm 1.85^{\mathrm{a}}$ & $48.3 \pm 1.85^{\mathrm{a}}$ & $48.3 \pm 1.85^{\mathrm{a}}$ \\
\hline $\mathrm{T}_{1}(10 \%)$ & $14.0 \pm 0.28^{\mathrm{b}}$ & $12.5 \pm 0.26^{\mathrm{b}}$ & $16.5 \pm 0.28^{\mathrm{b}}$ & $17.5 \pm 0.73^{\mathrm{b}}$ & $18.0 \pm 1.07^{\mathrm{b}}$ \\
\hline $\mathrm{T}_{2}(25 \%)$ & $13.2 \pm 0.17^{\mathrm{b}}$ & $11.2 \pm 0.05^{\mathrm{b}}$ & $15.3 \pm 173^{\mathrm{b}}$ & $16.4 \pm 0.14^{\mathrm{b}}$ & $17.4 \pm 0.81^{\mathrm{b}}$ \\
\hline $\mathrm{T}_{3}(50 \%)$ & $12.6 \pm 0.14^{\mathrm{b}}$ & $8.06 \pm 0.29^{\mathrm{c}}$ & $14.6 \pm 0.33^{\mathrm{b}}$ & $15.7 \pm 2.12^{\mathrm{b}}$ & $16.6 \pm 0.72^{\mathrm{b}}$ \\
\hline $\mathrm{T}_{4}(75 \%)$ & $8.52 \pm 0.02^{\mathrm{c}}$ & $5.82 \pm 0.04^{\mathrm{c}}$ & $10.4 \pm 0.08^{\mathrm{c}}$ & $14.6 \pm 0.197^{\mathrm{b}}$ & $10.1 \pm 0.17^{\mathrm{c}}$ \\
\hline $\mathrm{T}_{5}(100 \%)$ & $7.66 \pm 0.03^{\mathrm{c}}$ & $3.703 \pm 0.009^{\mathrm{d}}$ & $8.74 \pm 0.009^{\mathrm{c}}$ & $9.90 \pm 0.048^{\mathrm{c}}$ & $10.1 \pm 0.21^{\mathrm{c}}$ \\
\hline CD at $p<0.05$ & 2.40 & 2.41 & 2.44 & 3.71 & 3.07 \\
\hline SEM & 0.77 & 0.77 & 0.78 & 1.19 & 0.98 \\
\hline
\end{tabular}

Table 4: Efficacy of antagonists against Fusarium solani on $7^{\text {th }}$ day after inoculation

\begin{tabular}{|l|l|l|l|l|l|}
\hline Treatments & A. flavus & A. luchuensis & P. citrinum & P.chryosogenum & T. viride \\
\hline $\mathrm{T}_{0}($ Control $)$ & $61.3 \pm 2.84^{\mathrm{a}}$ & $61.3 \pm 2.8^{\mathrm{a}}$ & $61.3 \pm 2.84^{\mathrm{a}}$ & $61.3 \pm 2.84^{\mathrm{a}}$ & $61.3 \pm 2.84^{\mathrm{a}}$ \\
\hline $\mathrm{T}_{1}(10 \%)$ & $15.1 \pm 0.11^{\mathrm{b}}$ & $12.5 \pm 0.23^{\mathrm{b}}$ & $20.7 \pm 0.35^{\mathrm{b}}$ & $22.1 \pm 1.49^{\mathrm{b}}$ & $21.5 \pm 0.99^{\mathrm{b}}$ \\
\hline $\mathrm{T}_{2}(25 \%)$ & $13.7 \pm 0.20^{\mathrm{b}}$ & $11.3 \pm 0.05^{\mathrm{b}}$ & $17.4 \pm 0.39^{\mathrm{c}}$ & $20.0 \pm 1.10^{\mathrm{b}}$ & $21.0 \pm 0.63^{\mathrm{b}}$ \\
\hline $\mathrm{T}_{3}(50 \%)$ & $12.9 \pm 0.05^{\mathrm{b}}$ & $8.20 \pm 0.32^{\mathrm{b}}$ & $17.7 \pm 0.03^{\mathrm{c}}$ & $19.1 \pm 0.95^{\mathrm{b}}$ & $21.0 \pm 1.01 \mathrm{~b}$ \\
\hline $\mathrm{T}_{4}(75 \%)$ & $9.03 \pm 0.08^{\mathrm{c}}$ & $5.89 \pm 0.05^{\mathrm{b}}$ & $12.8 \pm 0.14^{\mathrm{d}}$ & $16.6 \pm 0.08^{\mathrm{b}}$ & $12.8 \pm 0.12^{\mathrm{c}}$ \\
\hline $\mathrm{T}_{5}(100 \%)$ & $7.76 \pm 0.03^{\mathrm{c}}$ & $3.75 \pm 0.01^{\mathrm{b}}$ & $10.6 \pm 0.08^{\mathrm{d}}$ & $12.5 \pm 0.26^{\mathrm{b}}$ & $12.2 \pm 0.21^{\mathrm{c}}$ \\
\hline CD at $p<0.05$ & 3.63 & 3.65 & 3.69 & 4.50 & 4.14 \\
\hline SEM & 1.16 & 1.17 & 1.18 & 1.44 & 1.32 \\
\hline
\end{tabular}

SEM: Standard error mean, Mean of radial growth in $(\mathrm{mm})$.Data are expressed as mean $\pm \mathrm{SE}(\mathrm{n}=3)$. Means within the same column and followed by the different letter are significantly different from each other according to Duncan's Multiple Range Test at $\mathrm{p}<0.05$ level of significance. 


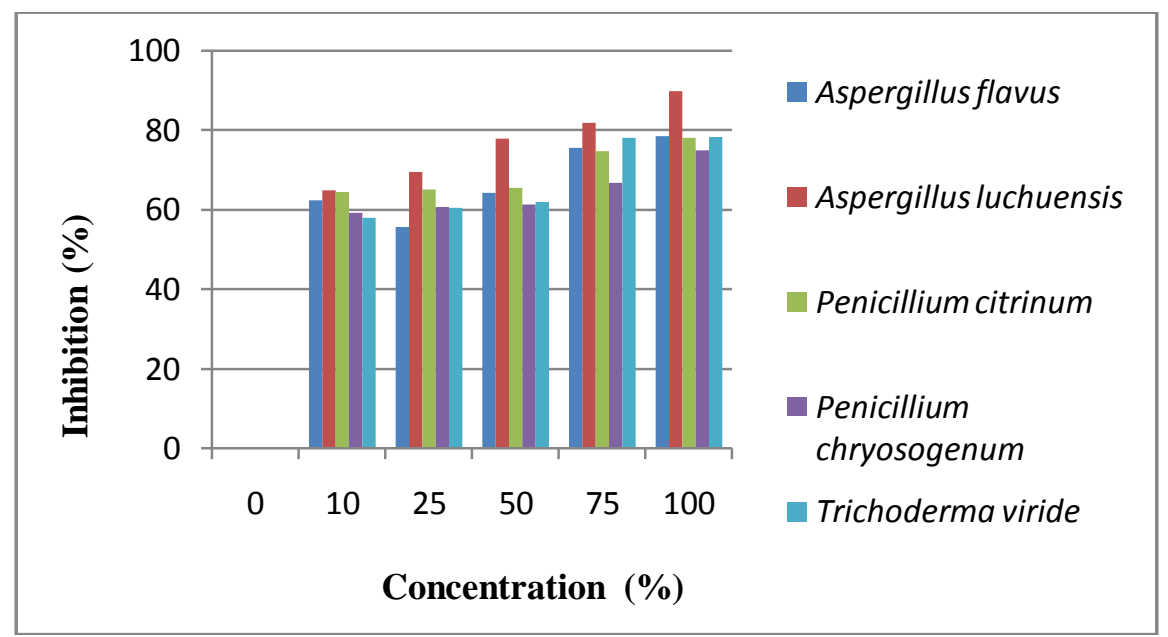

Fig 1: Percent inhibition of Fusarium solani on $3^{\text {rd }}$ day after inoculation at different concentration.

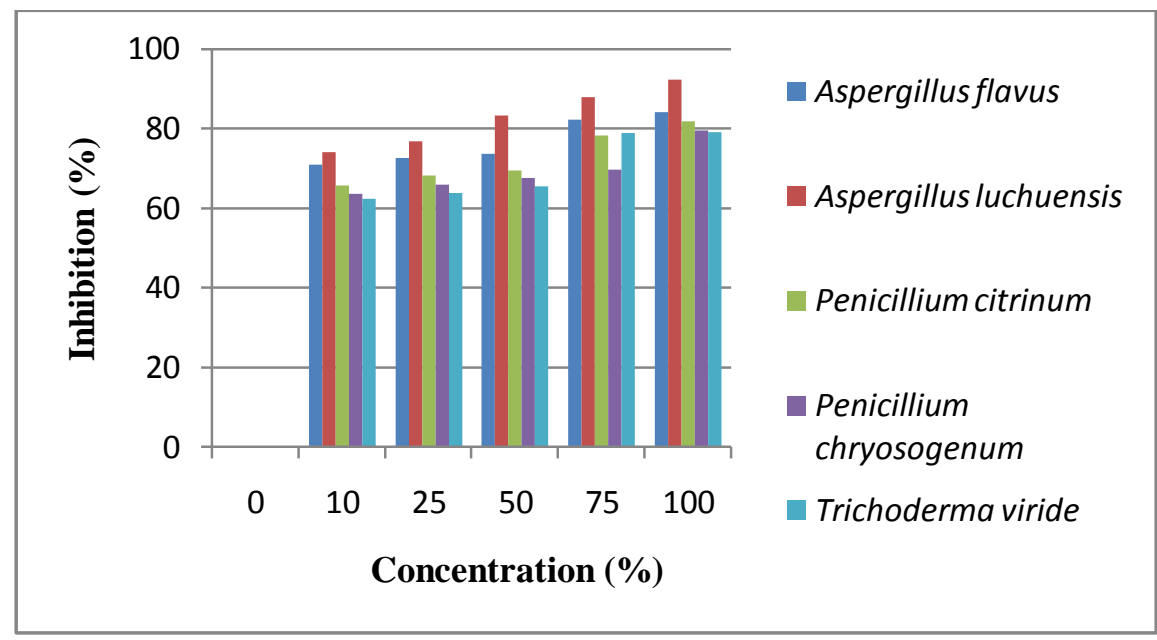

Fig 2: Percent inhibition of Fusarium solani on $5^{\text {th }}$ day after inoculation at different concentration

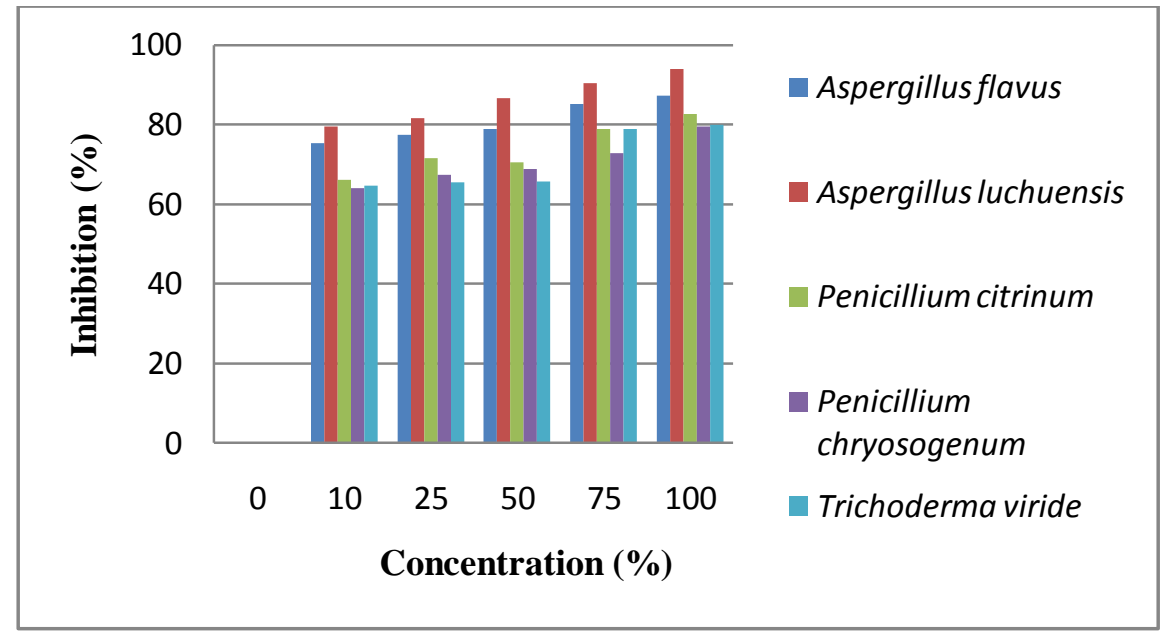

Fig 3: Percent inhibition of Fusarium solani on $7^{\text {th }}$ day after inoculation at different concentration. 
IOSR Journal of Engineering

May. 2012, Vol. 2(5) pp: 1217-1223

\section{CONCLUSION}

In the present study the concentration of 10, 25 and 50\% were not effective to diminish the radial growth of test pathogen but as the concentration was increased from 75 to $100 \%$ they inhibited the mycelial growth of pathogen at different levels. Results revealed that percent inhibition is dependent on concentration and duration of observation after inoculation. Based on the observation in the present findings, the effective fungal antagonists may be exploited as biopesticides in field condition for complete elimination of the wilt pathogens from the soil.

\section{ACKNOWLEDGEMENTS}

The authors are thankful to the Head, department of Environmental Science, B.B.A.U, Lucknow for providing infrastructure and research facilities. One of the author; Neetu Dwivedi is grateful to the UGC, New Delhi for providing UGC Non- Net fellowship.

\section{REFERENCES}

[1] V.S. Jaiswal and M, N. Amin, Guava and jack fruit in: Hammerschlag f.a., litz R.E. (eds), Boitechnology in agri. culture. (8) CAB international, walling ford, U.K. 1992, 421-431

[2] M.K. Rai, V.S Jaiswal and U. Jaiswal, Alginate- encapsulation of nodal segment of guava (psidium guajava) for germplasm exchange and distribution. J. Hort. sci. Biotec, (83) 2008, 569-573

[3] Bikash and B. Singh, Inhibition of virus transmission by guava leaf extract, Indian Phytopath, 54 (3) 2001, 381-382.

[4] M.K. Rai, N. Akhtar and V.S. Jaiswal, Somatic embryogenesis and plant regeneration in Psidium guajava L. C.V. Banarasi local Sci. Hort (113) 2007, 129-133.

[5] D.Gupta, S.N. and J.N. Rai. Wilt disease of guava (P. guajava), Curr. Sci, (16) 256-258.

[6] N. Prasad, P.R.Mehta and S.B. Lal, Fusarium wilt of guava ( Psidium guajava L.) in Uttar Pradesh, India. Nature, (169) 1952,753

[7] J.C. Edward, and R.N Srivastava, RE 502 Studies on guava wilt. Allahabad farmer, (31)1957, 144-146

[8] R. R. Pandey and R.S. Dwivedi, Fusarium oxysporum f. sp. Psidii as a pathogen causing Wilt of Guava in Varanasi District India. Phytopath . Z, (114) 1985, 243-248

[9] R.N. Tandon, and R.K.Agarwal, Reported wilt and dieback of guava due to Rhizoctonia sp. Proc. Indian Acad. Sci, (40) 1954, 102-109.

[10] S.K. Dwivedi, Efficacy of some antibiotics on Fusarium oxysporum f.sp. psidii causing wilt disease of guava.Hindustan Antibiotics Bulletin., 32(3-4) 1990, 88-90.

[11] S .K. Dwivedi and P. Dwivedi, Wilt disease of Guava a national problem, J. Appl. Hort, 1 (2) 1999, 151-154.

[12] S .K. Dwivedi, guava wilt incited by Macrophomina phaseolina, Nat. Acad. Sci. Letter, India, 13 (8) 1990, 302-303

[13] A.K. Mishra,Wilt of Guava -A disease of national importance Indian Phytopath, (59) 2006, 269-280

[14] A.K. Misra, and B.K. Pandey, Progressive natural wilting of guava plants during different months, Indian Phytopathol, (53) 2000, 423-427.

[15] A.K. Mishra and S. Shukla, National Seminar on Production and Post -Harvest Technology of Guava, Department of Horticulture. CSAUA\&T. Kanpur.9-10 Jan 2002, 34-35

[16] A.R. Sundar, N.D. Das and D. Krishnaveni, In vitro antagonism of Trichoderma species spp. against two fungal pathogens of Castor, Indian J. Plant Protec. 23 (2) 1995, 152-155

[17] J. Zhang, C.R. Howell, J.L. Star and M.H. Wheeler, Frequency of isolation and the pathogenicity of fusarium species associated with roots of healthy cotton seedlings, Mycol. Res.(6) 1995, 747-752.

[18] D. Kumar and S.C. Dubey, Management of collar rot of pea by the integration of biological and chemical methods, Indian phytopath, 54 (1) 2001, 62-66.

[19] S.B. Chattopadhyay and S.K. Battacharja, Investigation on the wilt disease of Guava (Psidium guajava) in West Bengal I. Indian J. Agri. Sci, 1968, 38-72.

[20] A.K. Mishra andB.K. Pandey, Pathogenicity and evaluation of fungicides against guava wilt pathogen, J. Mycol Pl. Pathol, (29)1999, 274-275.

[21] V.K. Gupta and A.K. Mishra, Microsatellite marker- based detection of Fusarium wilt pathogens of Psidium guajava L., Archives of phytopathology and plant protection, 44 (20) 2011, 1926-1941.

[22] J. Dolly, P. Gupta and V. Gupta Etiology and management of guava wilt disease in Allahabad and Kaushambi Districts of Uttar Pradesh, India, J. Mycol. Pl. Pathol., 36 (3) 2006, 365-72

[23] V.K. Gupta, A.K. Mishra, B.K. Pandey, R.A. Ram, S.P. Mishra and U.K. Chauhan, Evaluation of eco- friendly antagonists isolated from leaf based liquid biodynamic pesticides against guava wilt disease caused by Fusarium sp., Journal of Eco- friendly Agriculture, 4 (1) 2009, 77-79.

[24] V.K. Gupta, A.K. Mishra and B.K. Pandey, Histipathological changes in guava root during wilting induced by Fusarium spp.,Archives of pathology and plant protection, (1) 2011, 1-4. 
IOSR Journal of Engineering

May. 2012, Vol. 2(5) pp: 1217-1223

[25] S.K. Dwivedi, In vitro studies on the effect of some pesticides on Fusarium oxysporumf. sp. psidii causing wilt disease of guava, J. Ind. Bot. Soc, (70) 1991 283-285.

[26] Siva, N. S., Ganesan, N., Banumathy., and Muthuchelian., (2008), Antifungal effect of leaf extract of some medicinal plants against Fusarium oxysporum causing wilt disease of Solanum melogena L.Ethnobotanical leaflets 12: pp156-163

[27] B.O. Obongoya, S.O. Wagai, G. Odhiambo, Phytotoxic effect of selected crude plant extracts on soil-borne fungi of common bean. Afr. Crop Sci. J, 18(1) 2010, 15-22.

[28] N.B. Gangadara, Saifulla, R. Nagaraja and M.K. Basavaraja, Biological control of Fusarium oxysporum f. sp. Vanillae, the causal agent of stem rot of vanilla in vitro, I.J.S.N, 1 (2) 2010, 259-261.

[29] S.K. Dwivedi, Effect of culture filtrate of soil microbes of pathogens inciting wilt disease of guava (Psidium guajava L.) under in vitro conditions, Natl. Acad. Sci. Lett., (15) 1992, 33-35

[30] S.H.Singh, V.Ratan, G.S. Gaur and D. Gangwar, 2003. Evaluation of antagost against guava wilt pathogen, Farm sci. J, (12) 58-59.

[31] A.K. Mishra and B. Prasad, Trichoderma a genus for biocontrol, biopesticides and bio-agents. In RP Srivastava. 2003. Integrated pest management in agriculture crops.

[32] V.K. Gupta, and A.K. Misra, Efficacy of bioagents against Fusarium wilt of guava. J. Mycol. Plant Pathol., (39) 2009, 101-106.

[33] Shovan, L.R., Bhuiyan, M. K. A., Begum, J. A., and Pervez, Z., (2008), In vitro Control of Colletotrichum dematium Causing Anthracnose of Soybean by Fungicides, Plant Extracts and Trichoderma harzianum. Int. J. Sustain. Crop Prod. 3(3): pp10-17

[34] K.K. Pandey and J.P.Upadhyay, Microbial population from rhizosphere and non rhizospher soil of pigeonpea screening for resident antagonist and mode of mycoparasitism, J. Mycol. Pl. Pathol. (30) 2000 7-10.

[35] H. A. Alwathnani and K. Perveen, Biological control of fusarium wilt of tomato by antagonist fungi and cynobacteria, African journal of biotechnology, 11 (5) 2012, 1100-1105.

[36] S.U. Rani, R. Udayakumar and D. J. Christopher, Bio-efficacy of plant extracts and bio-control against Macrophomina phaseolina, Ann. Pl. Protec. Sci, 17 (1) 2009, 389-393.

[37] N. Sultana and A. Ghaffar, Effect of fungicides, microbial antagonists and oilcakes in control of fusarium solani, the cause of seed rot, seedling and root infection of bottle gourd and cucumber, Pak. J. Bot, 42 (4) 2010, 2921-2934.

[38] G. Segarra, E. Casanova, M. Aviles and I. Trillas, Trichoderma asperellum strain T34 controls fusarium wilt disease in Tomato plants in soilless culture through competition for iron, Microb. Ecol, (59) 2010, 141-149. 